\section{Body composition, metabolic syndrome and insulin resistance in type 1 diabetes mellitus}

\author{
Composição corporal, síndrome metabólica e \\ resistência insulínica no diabetes melito tipo 7
}

Denise Prado Momesso', Isabela Bussade 1,2, Giovanna A. Balarini Lima', Leniane Pereira Coelho Fonseca' ${ }^{1}$, Luis Augusto Tavares Russo'3 ${ }^{3}$ Rosane Kupfer ${ }^{1}$
1 Department of Diabetes, State Institute of Diabetes and Endocrinology, Universidade Católica do Rio de Janeiro (PUCRJ), Rio de Janeiro, RJ, Brazil ${ }^{2}$ Clinical and Experimental Research Laboratory on Vascular Biology - BioVasc, Biomedical Center, Universidade do Estado do Rio de Janeiro (UERJ), Rio de Janeiro, RJ, Brazil ${ }^{3}$ CCBR Brasil, Center for Basic and Clinical Research, Rio de Janeiro, RJ, Brazil tabolic risk. Arq Bras Endocrinol Metab. 2011;55(3):189-93

\title{
Keywords
}

Type 1 diabetes; body composition; metabolic syndrome; insulin resistance

\section{RESUMO}

Objetivo: Avaliar a relação entre composição corporal, síndrome metabólica (SM) e resistência insulínica (RI) no diabetes tipo 1 (DM1). Sujeitos e métod os: Quarenta e cinco mulheres com DM1 $\left(36 \pm 9\right.$ anos; índice de massa corporal $\left.24,6 \pm 4,4 \mathrm{~kg} / \mathrm{m}^{2}\right)$ foram submetidas à análise de composição corporal e RI por meio de densitometria por dupla emissão de raios-X e taxa de disponibilização de glicose estimada (eGDR), respectivamente. Vinte mulheres (45\%) apresentavam SM, conforme critérios da Organização Mundial da Saúde (OMS). Resultados: Mulheres com SM apresentaram maior gordura central e menor eGDR do que as sem SM $(41,9 \pm 2,0$ vs. $33,7 \pm 1,8 \%$; $p=0,004$ e 4,99 $\pm 0,40$ vs. $8,37 \pm 0,39 ; p<0,0001)$. A gordura corporal total e a gordura periférica não diferiram entre os grupos. A gordura central foi inversamente correlacionada com eGDR $(r=-0,33 ; p=0,03)$. Conclusão: Deposição de gordura central em mulheres jovens não obesas com DM1 esteve associada com SM e RI. Avaliação da composição corporal pode ser importante na identificação de pacientes com risco metabólico elevado. Arq Bras Endocrinol Metab. 2011;55(3):189-93

\section{Descritores}

Diabetes tipo 1; composição corporal; síndrome metabólica; resistência insulínica

\section{INTRODUCTION}

$\mathrm{M}$ etabolic syndrome (MS) is characterized by the clustering of independent cardiovascular risk factors including insulin resistance, central obesity, impaired glucose metabolism, hypertension, and dyslipidemia (1-4). MS and its insulin resistance have been associated with unfavorable outcomes such as heart disease and kidney disease both in type 2 diabetic patients and in the gen- 
eral population $(5,6)$. Likewise, the association of type 1 diabetes mellitus (DM) and MS, also called "double diabetes", might also confer an increased chance of major complications, including coronary artery disease, renal failure, and diabetes-related death (7-13).

Obesity and visceral fat deposition play a key role in MS development in the general population (14-16). It has been observed that increasing body weight in young adult Brazilians can also affect type I DM patients. Usually, patients with type $1 \mathrm{DM}$ are normal-weighted, but central fat accumulation in this population might also be linked to insulin resistance and MS $(8,9,11)$. Therefore, the evaluation of body fat distribution in type 1 DM patients may be important to identify patients at risk of MS. Anthropometric measures are the most used methods of assessment, however, imaging techniques, such as computed tomography (CT), magnetic resonance imaging (MRI) and dual-energy X-ray absorptimetry (DEXA), are more precise. DEXA is an easy method for total body fat and regional fat evaluation. Regional fat distribution measured by DEXA as gynoid fat and android fat positively correlates with central and peripheral fat measured by MRI, respectively. This technique has been validated as a precise indirect method of visceral abdominal fat determination, with the advantage of having a cost lower than that of CT and MRI and no need of contrast media (17-22).

In the present study, non-obese women with type 1 DM were submitted to body fat analysis by DEXA and were evaluated for the presence of MS clinical parameters and insulin resistance. The aim of this study was to determine the relationship between body fat composition, metabolic syndrome, and insulin resistance in type 1 women with DM.

\section{SUBJECTS AND METHODS}

Forty-five women with type $1 \mathrm{DM}$, treated at Instituto Estadual de Diabetes e Endocrinologia (State Institute for Diabetes and Endocrinology), enrolled in this study. We obtained informed consent from all the subjects, and the local Ethics Committee approved the protocol. Patients had a mean age of $36 \pm 9$ years, mean diabetes duration of $18 \pm 9$ years, and mean BMI of $24.6 \pm$ $4.4 \mathrm{~kg} / \mathrm{m}^{2}$. All patients had been on continuous insulin therapy since diagnosis and had positive anti-GAD (glutamic acid descarboxylase) auto-antibodies.

Metabolic syndrome was defined according to the World Health Organization (WHO) consensus criteria modified by EGIR (2). The modified WHO definition requires the presence of glucose intolerance or diabetes and/or insulin resistance for diagnosis and two of the following: 1) hypertension, defined as antihypertensive treatment and/or elevated blood pressure (systolic $\geq$ $160 \mathrm{mmHg}$ or diastolic $\geq 90 \mathrm{mmHg}$ ); 2) dyslipidemia, defined as elevated plasma triglycerides $(\geq 150 \mathrm{mg} / \mathrm{dL}$ ) and/or low HDL cholesterol ( $<39 \mathrm{mg} / \mathrm{dL}$ in women); $3)$ obesity, defined as high waist-to-hip ratio (WHR) ( $\geq 0.85$ in women); 4 ) microalbuminuria (urine albumin excretion rate $\geq 20 \mathrm{mcg} / \mathrm{min}$ ).

After evaluation of MS clinical parameters, patients were divided in two groups according to the presence of MS: 1) Type 1 diabetes with MS; 2 ) Type 1 diabetes without MS. Using the WHO criteria, 20 type 1 diabetic patients had MS.

Weight (in kilograms - $\mathrm{kg}$ ) and height (in meters - $\mathrm{m}$ ) were measured with the subjects wearing only their undergarments. Body mass index (BMI) was calculated as body weight divided by height squared $\left(\mathrm{kg} / \mathrm{m}^{2}\right)$. Waist (WC) and hip circumferences (in centimeters $\mathrm{cm}$ ) were measured in the midline between the lower rib margin and the iliac crest, and widest diameter over the greater trochanters, respectively, while the subjects were standing with their heels together. Waist-to-hip ratio (WHR) was obtained.

Fasting blood samples were collected and analyzed for glycated hemoglobin (HbAlc) and lipids. HbAlc concentrations were measured by high-pressure liquid chromatography with a reference range of $4 \%-6 \%$ (Variant II, Biorad). Serum total cholesterol, HDL cholesterol and triglycerides were measured by a calorimetric enzymatic assay (Advia, Siemens). LDL cholesterol was calculated using the Friedewald formula (23). Microalbuminuria (urine albumin excretion rate) was analyzed in a 24-hour urine sample and was determined by nefelometric method (BNII, Siemens).

Insulin resistance was calculated using the estimated glucose disposal ratio (eGDR), previously validated by Williams and cols., according to the following equation: 24.31- (12.22 x WHR) - 3.29 x HT) - 0.57 x HbAlc, where the units are $\mathrm{mg} \cdot \mathrm{kg}^{-1} \cdot \mathrm{min}^{-1}$, HT $=$ hypertension (24). Daily insulin dosage was calculated in units per kilogram body weight at baseline.

Total body dual-energy X-ray -absorptiometry (DEXA) was performed using a GE Lunar Prodigy Advance scanner (software 11.2, GE, Healthcare, Belgium). Total body and regional body fat composition were analyzed. Regional fat distribution was measu- 
red by DEXA as android and gynoid fat regions. Total body fat (TBF), android and gynoid fat regions were expressed as a percentage of the total body weight. The android to gynoid fat ratio $(A / G)$ was also determined. Android fat region is an estimate of central fat, while gynoid fat region correlates with peripheral fat. Android fat region has been shown to contain a relative high proportion of intra-abdominal fat and has been validated as a good indirect method of visceral fat prediction (17-22).

\section{Statistical analysis}

Statistical analysis was carried out using the program GraphPad Prism ${ }^{\circledast}$ (version 4.00 for Windows, GraphPad Software, San Diego, California, USA). Data were expressed as mean \pm standard deviation $(\mathrm{SD})$. Patient baseline characteristics and body fat composition in the two groups (type 1 diabetes with and without MS) were compared using an independent student ttest. The correlation between the parameters was tested by Pearson correlation. Statistical significance was set at $\mathrm{p}<0.05$.

\section{RESULTS}

Table 1 shows the clinical characteristics of type 1 DM women with and without MS. Prevalence of MS using WHO criteria was $45 \%$. There were no age or race differences between the groups. Duration of type $1 \mathrm{DM}$ was similar in subjects with and without MS, despite a non-statistic tendency ( $\mathrm{p}=0.06)$ of increased DM duration in subjects with MS. Mean BMI was $26.7 \pm$ $0.9 \mathrm{~kg} / \mathrm{m}^{2}$ in patients with MS and $23.0 \pm 0.8 \mathrm{~kg} / \mathrm{m}^{2}$ in patients without MS $(\mathrm{p}=0.0004)$. None of the subjects in the study had obesity, defined by a BMI > $30 \mathrm{~kg} / \mathrm{m}^{2}$. Patients with MS had increased waist circumference $(89.0 \pm 2.7 \mathrm{~cm}$ vs. $79.8 \pm 1.9 \mathrm{~cm} ; \mathrm{p}=0.006)$ and waist-to-hip ratio $(0.91 \pm 0.02 \mathrm{~cm} v s .0 .82 \pm 0.01 \mathrm{~cm}$, $\mathrm{p}=0.006)$. Metabolic syndrome was not associated with a worse glycemic control, since mean $\mathrm{HbAlc}$ were similar between the groups. Daily insulin dosage did not differ between the groups.

Body composition analysis by DEXA (Table 2) demonstrated an increased central fat distribution in the type 1 DM patients with MS group, with a higher android fat distribution and android-to-gynoid fat ratio $(\mathrm{A} / \mathrm{G})$ than patients without MS $(41.9 \% \pm 2.0 \% v s$. $33.7 \% \pm 1.8 \%, \mathrm{p}=0.004$; and $0.9 \% \pm 0.05 \%$ vs. $0.7 \% \pm$ $0.03 \%, \mathrm{p}=0.0002)$. Total body fat and gynoid fat dis- tribution were not different between the groups with and without MS $(38.4 \% \pm 1.8 \%$ vs. $35.4 \% \pm 1.4 \%, \mathrm{p}=$ 0.19 ; and $45.1 \% \pm 1.8 \%$ vs. $45.9 \% \pm 1.2 \%, \mathrm{p}=0.71$; respectively).

Type 1 diabetic patients with MS had a significantly lower mean eGDR than patients without MS $\left(4.99 \pm 0.40\right.$ vs. $8.37 \pm 0.39$ mg.kg ${ }^{-1} \cdot \mathrm{min}^{-1} ; \mathrm{p}<$ 0.0001 ) (Figure 1). There was a negative correlation between eGDR and android fat distribution $(\mathrm{r}=-0.33$; $\mathrm{p}=0.03)($ Figure 2$), \mathrm{A} / \mathrm{G}$ ratio $(\mathrm{r}=-0.5 \mathrm{l} ; \mathrm{p}=0.0004)$, WC $(\mathrm{r}=-0.50 ; \mathrm{p}<0.0001)$, and WHR $(\mathrm{r}=-0.63$; $\mathrm{p}<0.0001)$. No correlation was found between eGDR and total body fat $(\mathrm{r}=-0.12 ; \mathrm{p}=0.41)$, gynoid fat distribution $(\mathrm{r}=0.13 ; \mathrm{p}=0.39)$ or microalbuminuria $(\mathrm{r}=-0.21 ; \mathrm{p}=0.16)$.

Table 1. Characteristics of type $1 \mathrm{DM}$ women with and without metabolic syndrome

\begin{tabular}{lccc}
\hline N & $\begin{array}{c}\text { DM 1 } \\
\mathbf{2 5}\end{array}$ & $\begin{array}{c}\text { DM 1 + MS } \\
\mathbf{2 0}\end{array}$ & p-value \\
\hline Age (years) & $34.9 \pm 2.1$ & $37.6 \pm 1.7$ & 0.35 \\
Caucasian & $17(68 \%)$ & $15(75 \%)$ & 0.61 \\
Diabetes duration (years) & $15.8 \pm 1.9$ & $21.1 \pm 2.0$ & 0.06 \\
Hypertension & $2(8 \%)$ & $13(65 \%)$ & $0.00006^{*}$ \\
Cigarette smoking & $2(8 \%)$ & $2(10 \%)$ & 0.61 \\
BMl (kg/m²) & $23.0 \pm 0.8$ & $26.7 \pm 0.9$ & $0.004^{*}$ \\
WC (cm) & $79.8 \pm 1.9$ & $89.0 \pm 2.7$ & $0.006^{*}$ \\
WHR & $0.82 \pm 0.01$ & $0.91 \pm 0.02$ & $<0.0001^{*}$ \\
LDL cholesterol (mg/dL) & $91.7 \pm 5.8$ & $109.8 \pm 8.1$ & 0.07 \\
HDL cholesterol (mg/dL) & $59.2 \pm 2.3$ & $47.1 \pm 2.9$ & $0.0019^{*}$ \\
Triglycerides (mg/dL) & $64.6 \pm 4.8$ & $144.1 \pm 19.3$ & $<0.0001^{*}$ \\
Microalbuminuria (mcg/min) & $8.1 \pm 0.8$ & $22.7 \pm 7.4$ & $0.033^{*}$ \\
HbA1c (\%) & $8.6 \pm 0.4$ & $8.6 \pm 0.5$ & 0.92 \\
Insulin dosage (U/kg) & $0.8 \pm 0.1$ & $0.8 \pm 0.1$ & 0.24 \\
\hline
\end{tabular}

BMI: body mass index; WC: waist circumference; WHR: waist-to-hip ratio; HbA1c: glycated hemoglobin. Values are expressed as mean $\pm S D$, except for values related to hypertension and cigarette smoking which represent the absolute number of patients.

${ }^{*}$ Statistical significance $(p<0.05)$.

Table 2. Body composition by DEXA in type $1 \mathrm{DM}$ women with and without metabolic syndrome

\begin{tabular}{lccc}
\hline & DM 1 & DM 1 + MS & p-value \\
\hline Total body fat (\%) & $35.4 \pm 1.4$ & $38.4 \pm 1.8$ & 0.19 \\
Android fat (\%) & $33.7 \pm 1.8$ & $41.9 \pm 2.0$ & $0.004^{*}$ \\
Gynoid fat (\%) & $45.9 \pm 1.2$ & $45.1 \pm 1.8$ & 0.71 \\
A/G & $0.7 \pm 0.03$ & $0.9 \pm 0.05$ & $0.0002^{*}$ \\
\hline
\end{tabular}

Values are mean $\pm S D$. * Statistical significance $(p<0.05)$.

Total body fat (TBF), android and gynoid fat regions were expressed as a percentage of total body weight. Android fat and gynoid fat correspond to central and peripheric fat distribution, respectively. A/G: android-to-gynoid fat ratio. 


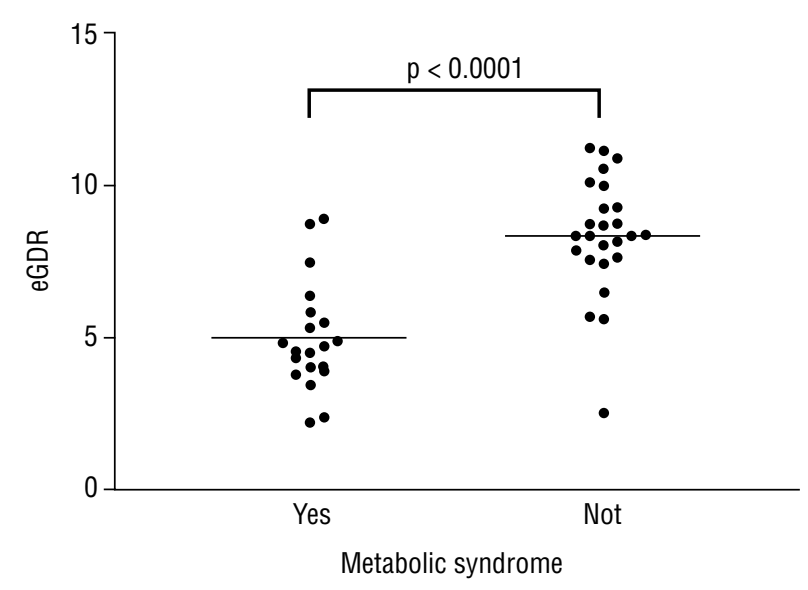

Figure 1. Estimated eGDR $\left(\mathrm{mg} \cdot \mathrm{kg}^{-1} \cdot \mathrm{min}^{-1}\right)$ in type $1 \mathrm{DM}$ women with and without metabolic syndrome.

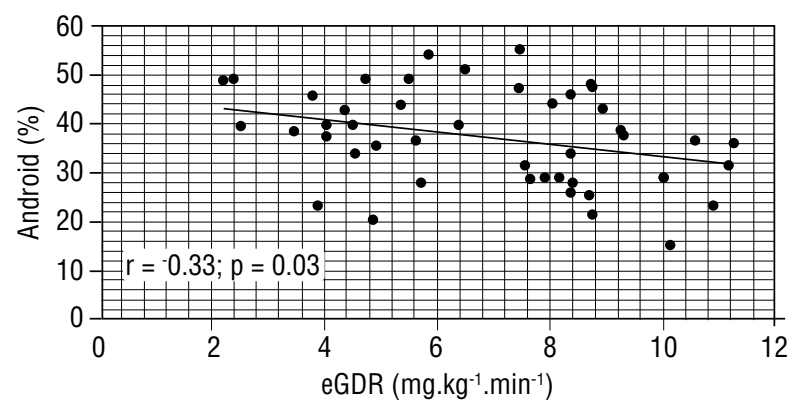

Figure 2. Correlation between eGDR and android fat deposition.

Patients with type $1 \mathrm{DM}$ and MS had significantly higher triglyceride levels $(144.1 \pm 19.3 \mathrm{mg} / \mathrm{dL} v s .64 .6$ $\pm 4.8 \mathrm{mg} / \mathrm{dL} ; \mathrm{p}<0.0001)$ and lower HDL levels (47.1 $\pm 2.9 \mathrm{mg} / \mathrm{dL}$ vs. $59.2 \pm 2.3 \mathrm{mg} / \mathrm{dL} ; \mathrm{p}=0.0019)$, with a tendency of higher LDL levels $(109.8 \pm 8.1 \mathrm{mg} / \mathrm{dL} v s$. $91.7 \pm 8.1 \mathrm{mg} / \mathrm{dL} ; \mathrm{p}=0.07$ ) (Table $\mathrm{l}$ ), when compared to those without MS. Android fat distribution was positively correlated with LDL cholesterol $(\mathrm{r}=0.38 ; \mathrm{p}=$ $0.01)$ and triglycerides $(\mathrm{r}=0.35 ; \mathrm{p}=0.019)$. A negative correlation was found with android fat distribution and HDL cholesterol $(\mathrm{r}=-0.38 ; \mathrm{p}=0.01)$. No correlation was found between gynoid fat distribution and LDL, HDL cholesterol or triglyceride levels (Table 3).

Table 3. Correlation between android (central) fat deposition (\%) and lipid profile $(\mathrm{mg} / \mathrm{dL})$ in women with type $1 \mathrm{DM}$

\begin{tabular}{lcc}
\hline & $\mathbf{r}$ & p-value \\
\hline LDL cholesterol & 0.38 & $0.010^{\star}$ \\
HDL cholesterol & -0.38 & $0.019^{\star}$ \\
Triglycerides & 0.35 & $0.010^{\star}$ \\
\hline
\end{tabular}

${ }^{*}$ Statistical significance $(p<0.05)$.

\section{DISCUSSION}

The present study demonstrated that non-obese type 1 diabetic women with predominant central fat deposition exhibit MS clinical parameters and increased insulin resistance, what might confer an increased cardiometabolic risk.

We observed a high prevalence of MS (45\%) in young adult women with type $1 \mathrm{DM}$ using the WHO criteria. These criteria appear to have the highest sensitivity to discriminate negative outcomes in patients with type 1 diabetes $(10,13)$. A previous study from our group critically analyzed different criteria for MS in type $1 \mathrm{DM}$. It was observed that the $\mathrm{WHO}$ criteria were the preferred method to identify MS in this population, in comparison to IDF and NCEP criteria, and MS was found in $30 \%$ of women and $34 \%$ of men with type 1 DM (13). Prior studies also observed that the prevalence of MS in type $1 \mathrm{DM}$ is as high as $30 \%-45 \%$, what can be linked with adverse outcomes $(8,10-12,14)$.

Body composition evaluation was important to identify patients with clinical parameters of MS. We found that increased central fat deposition was a major determinant of MS in non-obese type 1 diabetic women. Type I DM with MS had increased WC and WHR (Table 1). Using DEXA, these patients also had a higher android (central) fat distribution and A/G ratio. Nonetheless, total body fat and gynoid (peripheric) fat distribution were not related to MS (Table 2). Some patients with MS were overweight, but none had obesity. Thus, our data gives further evidence that predominant central obesity is a risk factor for MS in type $1 \mathrm{DM}$.

Insulin resistance has been recognized as an important feature in type $1 \mathrm{DM}(9,11,25-27)$. It has been demonstrated that insulin resistance is a predictor of coronary artery disease in type 1 diabetes (27). Clinically, it is often difficult to accurately identify insulin resistance in type 1 DM. Recently, eGDR has been developed and validated as an easy method of insulin resistance evaluation in type 1 diabetes (24). In the present study, type I DM patients with MS had decreased eGDR, which indicates diminished insulin sensitivity (Figure 1). Central obesity was also associated with insulin resistance since there was an inverse correlation between eGDR and WC, WHR and android fat distribution (Figure 2). No correlation was found between eGDR with peripheric fat distribution, represented by the gynoid fat region. Therefore, our data suggest that MS and body fat distribution, particularly central fat tissue, are significantly correlated with insulin resistance in type 1 DM. The Pittsburg Study also described a reduced eGDR in type $1 \mathrm{DM}$ with MS (10). In that study, eGDR was the 
best predictor for renal failure and also predicted coronary artery disease and diabetes related mortality (10).

The presence of clinical parameters of MS in young adult women with type 1 diabetes was accompanied by increased microalbuminuria, hypertension and the worst lipid profile in this study (Table 1), which are well known cardiovascular risk factors. Central fat deposition, but not peripheric fat, was associated with higher LDL cholesterol and triglyceride content and lower HDL cholesterol (Table 3). Therefore, type $1 \mathrm{DM}$ with MS and central obesity accumulates several atherogenic risk factors at young age, which will probably contribute for an adverse cardiovascular outcome (10-12,26,27).

In conclusion, central fat deposition in non-obese type 1 DM women was related to MS and insulin resistance. Furthermore, young adult women with MS and/or central obesity accumulate several cardiovascular risk factors, such as insulin resistance, microalbuminuria, hypertension and atherogenic lipid profile. Thus, body composition analysis with identification of central fat deposition might be important to identify non-obese type $1 \mathrm{DM}$ patients with increased cardiometabolic risk. Further studies with a greater number of patients are necessary to corroborate these data.

Acknowledgements: Authors are grateful to Dr. Martha Cecilia Suárez-Mutis for the statistical analysis and to Andreia Maria do Amaral Bruni, Rosangela Adriano Barbosa and Patricia Cotilha de Andrade de Sena for their technical assistance.

Disclosure: no potential conflict of interest relevant to this article was reported.

\section{REFERENCES}

1. Reaven GM. Role of insulin resistance in human disease (syndrome X): an expanded definition. Ann Rev Med. 1993;44:121-31.

2. Balkau B, Charles MA. Comment on the provisional report from the WHO consultation. European group for the study of insulin resistance (EGIR). Diabet Med. 1999;16:442-3.

3. Laaksonen DE, Lakka HM, Niskanen L, Kaplan GA, Salonen JT, Lakka TA. Metabolic syndrome and development of diabetes mellitus: application and validation of recently suggested definitions of the metabolic syndrome in a prospective cohort study. Am J Epidemiol. 2002;156:1070-7.

4. Picon PX, Zanatta CM, Gerchman F, Zelmanowitz T, Gross JL, Canani LH. Analysis of the criteria used for the definition of metabolic syndrome in patients with type 2 diabetes. Arq Bras Endocrinol Metabol. 2006;50:264-70.

5. Isomaa B, Almgren P, Tiinamaija T, Forsén B, Lahti K, Nissén M, et al. Cardiovascular morbidity and mortality associated with the metabolic syndrome. Diabetes Care. 2001;24:683-9.

6. Haffner SM. The metabolic syndrome: inflammation, diabetes mellitus, and cardiovascular disease. Am J Cardiol. 2006;97:3-11.

7. Teupe B, Bergis K. Epidemiological evidence for "double diabetes". Lancet. 1991;337:361-2.

8. Thorn LM, Forsblom C, Fegerudd J, Thomas MC, Petterson-Fernholm K, Saraheimo M, et al. Metabolic syndrome in type 1 diabetes. Diabetes Care. 2005;28:2019-24.
9. Dib SA. Insulin resistance and metabolic syndrome in type 1 diabetes. Arq Bras Endocrinol Metabol. 2006;50:250-63.

10. Pambianco G, CostacouT, OrchardTJ. The prediction of major outcomes of type 1 diabetes: a 12-year prospective evaluation of three separate definitions of the metabolic syndrome and their components and estimated glucose disposal rate. Diabetes Care. 2007;30:1248-54.

11. Kilpatrick ES, Rigby AS, Atkin SL. Insulin resistance, the metabolic syndrome, and complication risk in type 1 diabetes. Diabetes Care. 2007;30:707-12.

12. Davis TME, Bruce DG, Davis WA. Prevalence and prognostic implications of the metabolic syndrome in community-based patients with type 1 diabetes: the Fremantle Diabetes Study. Diabetes Res Clin Pract. 2007;78:412-7.

13. Santos CE, SchrankY, Kupfer R. Critical analyses of WHO, IDF and NCEP criteria for metabolic syndrome among patients with type 1 diabetes mellitus. Arq Bras Endocrinol Metab. 2009;53:1096-102.

14. Kissebah AH, Vydelingum N, Murray R, Evans DJ, Hartz AJ, Kalkhoff RK, et al. Relation of body fat distribution to metabolic complication of obesity. J Clin Endocrinol Metab. 1982;54:254-60.

15. Fujioka S, MatsuzawaY, Tokunaga K, Tarui S. Contribution of intra-abdominal fat accumulation to the impairment of glucose and lipid metabolism in human obesity. Metabolism. 1987;36:54-9.

16. Ribeiro Filho FF, Mariosa LS, Ferreira SRG, Zanella MT. Gordura visceral e síndrome metabólica: mais do que uma simples associação. Arq Bras Endocrinol Metabol. 2006;50:230-8.

17. Mazess RB, Barden HS, Bisek JP, Hanson J. Dual-X-ray-absorptiometry for total body and regional bone-mineral and soft-tissue composition. Am J Clin Nutr. 1990;51:1106-12.

18. Prior BM, Cureton KJ, Modlesky CM, Evans EM, Sloniger MA, Saunders $\mathrm{M}$, et al. In vivo validation of whole body composition estimates from dual-energy X-ray absorptiometry. J Appl Physiol. 1997;83:623-30.

19. Clasey JL, Bouchard C, Teates CD. The use of anthropometric and dual-energy X-ray absorptiometry (DXA) measures to estimate total abdominal and abdominal visceral fat in men and women. Obes Res. 1999;7:256-64.

20. Park YW, Hemsfield SB, Gallagher D. Are dual-energy X-ray absorptiometry regional estimates associated with visceral adipose tissue mass? Int J Obes Relat Metab Disord. 2002;26:978-83.

21. Norcross J, Van Loan MD. Validation of fan beam dual energy X-ray absorptiometry for body composition assessment in adults aged 18-45 years. Br J Sports Med. 2004;38:472- 6.

22. Lee CC, Glickman SG, Dengel DR, Brown MD, Supiano MA. Abdominal adiposity assessed by dual energy $\mathrm{X}$-ray absorptiometry provides a sex-independent predictor of insulin sensitivity in older adults. J Gerontol A Biol Sci Med Sci. 2005;60:872-8.

23. Friedwald WT, Levy RI, Fredrickson DS. Estimation of the concentration of low lipoprotein colesterol in plasma without use of preparative centrifugation. Clin Chem. 1972;18:499-502.

24. Williams K, Erbey J, Becker D, Arslanian S, OrchardT. Can clinical factors estimate insulin resistance in type 1 diabetes? Diabetes. 2000;49:626-32.

25. DeFronzo RA, Hendler $R$, Simonson D. Insulin resistance is a proeminent feature of insulin-dependent diabetes. Diabetes. 1982;31:795-801.

26. Yip J, Mattock MB, Morocutti A, Sethi M, Trevisan R, Viberti G. Insulin resistance in insulin-dependent diabetic patients with microalbuminuria. Lancet. 1993;342:883-7.

27. OrchardTJ, OIson JC, Erbey JR, Williams K, Forrest KY-Z, Smithline Kinder $L$, et al. Insulin resistance-related factors, but not glycemia, predict coronary artery disease in type 1 diabetes: 10-year follow-up from the Pittsburgh Epidemiology of Diabetes Complications study. Diabetes Care. 2003;26:1374-9. 